\title{
Trajectories through Vocational Education and Training
}

\author{
Kitt Margaret Lyngsnes \\ Nord University \\ Levanger, Norway \\ Marit Rismark \\ Norwegian University of Science and Technology \\ Trondheim, Norway
}

\begin{abstract}
This article presents a longitudinal study of students in vocational education in Norway. Statistics show that one third of the students do not complete their vocational education. In our study, we have followed 32 students over six years from the time they started their vocational education. The method was annual semi structured interviews. The aim of the study was to develop insights into how students tend to change course choices, occupational aspirations, and dispositions to learning as well as approaches to studentship throughout this significant period of their life. The intention has been to bring out the students' own descriptions, understandings and experiences related to the main research question: What choices do young people make regarding education and occupation and what is the background for these choices? The study draws upon the concept «learning trajectories». We describe findings from the study by using the three metaphors "stayers, movers and leavers". These categories describe the students' different learning trajectories. The category stayers describes those who have completed their planned education at the appointed time. Movers describes those who have changed courses along the way, and the category leavers describes those who do not complete upper secondary education.
\end{abstract}

Keywords: VET (vocational education and training); dropout; learning trajectories.

\section{Dropouts and change of choice in further education}

The high dropout rate in upper secondary education is a major challenge to educational programmes internationally. Upper secondary education in Norway faces a similar challenge. The majority of dropouts are students in vocational programmes, and a considerable number are apprentices in the workplace. 
A consequence of leaving education programmes without obtaining a diploma is having fewer opportunities in the job market and limited access to postsecondary education. Moreover, costs to society may be high as upper secondary school dropouts are more likely to be unemployed, to earn less, to have more difficult lives and to be on welfare (Falch \& Nyhus, 2009; Land \& Legters, 2002). With these high dropout rates and the ensuing personal, social and economic consequences, it is vitally important to examine how upper secondary educational systems can keep students connected throughout the programmes. Research has provided insights into several factors affecting the dropout rate along with their interrelations, where the main findings focus on the identification of characteristics of dropouts. Social background, gender, ethnicity, previous school outcomes and truancy are found to affect dropout rates (Beekhoven \& Dekkers, 2005; Byrhagen, Falch, \& Strøm, 2006; Fry, 2003; Markussen, 2011; Markussen, 2016; Patterson, Hale \& Stessman, 2007).

According to the Organisation for Economic Co-operation and Development (OECD), Norway has a well-developed vocational education and training system, which enjoys a high degree of confidence (Kuczera, Brunello, Field, \& Hoffman, 2008). Vocational education programmes in Norway follow a split model where the participants start out as students enrolled in a two-year school programme. This period is followed by a two-year apprenticeship at a workplace, framed by a national curriculum. The apprenticeship period is completed with a final examination and diploma.

In Norway, almost the whole year's cohort begins at upper secondary school after completed compulsory education (year 10). Five years later, however, there is a large proportion of students who do not have qualifications to enter a university or completed a vocational training for a trade. In $2016,86 \%$ of those who had started studying general studies education programs five years earlier had completed their study, while $59 \%$ of the students in vocational education programs had completed in the same period (Statistisk sentralbyrå, 2017). In a country with a knowledge-based economy where the labour market places high demands on employees' competence, it is expected that the population will complete upper secondary education. A high dropout rate and thus a lack of expertise come at a high socioeconomic cost. Dropout or change of choice issues are a central theme in the education policy agenda for many countries (Lamb, Markussen, Teese, Sandberg \& Polesel, 2011; Lillejord et al., 2015). Consequently, there is currently extensive research on dropout rates in Norway and internationally. A significant central research topic in this context is reasons why young people discontinue their upper secondary education. Markussen, Frøseth and Sandberg (2011) have summarized this research and found that the causes of dropout can be grouped into four main categories: 1) the background of the young people, 2) the young people's school achievements at earlier levels in the education system, 3) the young people's involvement in school and 4) the context of the education.

Concerning the first category, background, it appears that the likelihood of succeeding in upper secondary education increases according to what higher 
education the parents have, whether the parents are employed, whether parents consider education to be important and support the young people in their school work, whether parents live together and whether parents follow an authoritative style in the upbringing of their children. The likelihood of successfully completing upper secondary education is also greater for young people from majority groups compared to those from minority groupings, and for girls compared to boys (Markussen et al., 2011; Rumberger, 2011).

The category school achievements shows that the better the young people have done earlier in the years of compulsory schooling, the better they do in upper secondary school. A number of national and international surveys show that previous school results and the knowledge and skills that young people have acquired before they begin secondary education is the feature that has the greatest direct effect on the outcome of upper secondary education (Byrhagen, Falch \& Strøm, 2006; Markussen et al., 2011; Rumberger, 2011).

The third category deals with professional and social engagement in and with school. This is an important factor on the question of either completing or quitting upper secondary education. Markussen (2016, p. 35) explains commitment to school as follows: a) to experience school as an arena where one feels a sense of belonging, and with which one can identify; b) considering school as a venue where it is worthwhile to make an effort to learn in terms of future benefit; c) that one does, in fact, acquire knowledge. The likelihood of succeeding in upper secondary school is reduced with increasing absenteeism, behavioural problems and when students dread attending school. The probability of passing increases when students enjoy themselves, when they make an effort in their schoolwork, are motivated and have high educational ambitions.

The fourth category, context in which higher education takes place, also has a bearing on competence achievement. For example, it appears that there is a higher dropout rate in some counties than in others (Markussen, 2016). Furthermore, some education programs have higher dropout rates than others, even though the students had the same grade at enrolment (Byrhagen et al. 2006).

This grouping into four main categories shows a complex picture of reasons for young people quitting their upper secondary education. The many influences that are drawn from this are not disparate in effect. There is often a relationship between the influences. For example, students' involvement in school is often related to parents' background and to previous school achievements. The significance of acquiring an education is not equally appreciated in all homes. The consequence of this is that children and adolescents identify differently with school. This can also be of significance for involvement and results. Many have learned from their parents that education is necessary to succeed in the work place and society, and therefore they prioritize school attendance and involvement in school. Others may have learned that education is not so 
important, and this can lead to viewing school with indifference or scepticism and resistance.

When a student quits in upper secondary education it is rarely an abrupt and sudden decision. It is more likely the result of a long-term negative relationship with school and education, with a low level of involvement and weak performance at school. This process perspective in dropouts at upper secondary level is found in international research on dropout rates (Vibe, Frøseth, Hovdhaugen \& Markussen, 2012, p.221). This situation is reproduced and amplified over time in a downward spiral. This spiral may have started early in primary school. Conversely, a student who engages and identifies early with school and performs well enters a positive spiral in transition to upper secondary school. Barry and Reschly (2012) have completed a seven-year study of upper secondary school students in the United States, pointing to engagement as a key factor for students to complete their education. If students are engaged in their schooling, identifying with school and feeling a sense of belonging, the likelihood is that they complete schooling.

\section{Young people through vocational education - a longitudinal study}

In other words, there is extensive research on dropout problems. This research has highlighted various conditions and looked at dropouts from different perspectives. Much research relates to social conditions linked to the fact that many do not complete their education (e.g. Falch \& Nyhus, 2009; Falch, Johannesen \& Strøm, 2009). Other projects have studied students and which conditions are seen as risk factors for dropping out of upper secondary education. However, research looking at dropouts at an individual level is very retrospective. That is, the research has been done on young people who have quit their schooling and who, at a given time, look back at their choices and decisions. Their thoughts and reflections on what was important to them and what prompted them to quit, is thus done in retrospect. Consequently, there is little knowledge about what assessments the young people make when they are still in the midst of the choices or what thoughts they make before the choices that affect whether they complete or quit. There has been little research on young people along the way during the course of their education and very little on students who have completed their schooling. In this area there is a need for research that can provide a comprehensive and supplemental picture of why young people either complete or fail to complete upper secondary education. Such knowledge can be developed through researching students who are in different phases of the course of training. In the following, a study is described which was intended to illustrate those choices and assessments the young people make while in the course of their education. With this starting point, we have conducted a comprehensive study where we followed students for six years from the beginning of their vocational upper secondary education. Our aim was to describe and analyse the students' experiences, perceptions and assessments through their youth years in order to gain insight into the complex interaction between the different relationships that affect their choice of education and whether they complete that education. In order to gain insight 
into this complexity of pupils' paths through upper secondary education, the study has highlighted individual related relationships, as well as procedure and system related relationships, based on the following main research question: What choices do young people make regarding education and occupation and what is the background for these choices?

\section{Learning trajectories}

Bloomer and Hodkinson (2000a) have used the term "learning career" to describe the way through schooling to occupation "where career is seen as a contingent series of routines and transformations, rather than some planned or linear trajectory" (Hodkinson \& Hodkinson, 2003, p. 5). However, the word career gives associations with a predetermined, structured and successful direction for one's education and profession. It bears content that is perceived as a career process that is planned and built linearly. The term "learning trajectory" is used in different social science traditions and adds somewhat different content within the various disciplines (Lahn, 2011; Wittek \& Bratholm, 2014). Lahn (2011, p. 54) shows that "learning trajectories" and "learning career" include the same processes, and he points out that both of these terms emphasize the diverse, informal and multidimensional in learning processes within "life course research". In our context, we therefore are choosing to use the concept of learning trajectory to illuminate the different paths of young people through vocational education.

The term "learning trajectory" thus shows the dynamic, varied and flexible features in learning processes. It addresses the convoluted and complex elements in these processes and the movement that is initiated through participation in different contexts (Wittek, 2013; Wittek \& Bratholm, 2014). Learning trajectories are formed through participation in and across different contexts. Young people participate in many different contexts, through both education and leisure, with family, friends, fellow students, teachers, etc. The learning trajectories are personal and unique, but what constitutes them is what one experiences within different social contexts, and the meaning one creates from this (Wittek \& Bratholm, 2014). Our study thus focuses on the learning trajectories of young people and what helps shape them from when they commence upper secondary education, during their training and the period immediately afterwards. A learning trajectory will be developed and changed over time and can only be understood "[...] through their past lives, including their position in relation to various fields that they occupied, together with their experiences and interactions with others, in the past and present" (Hodkinson \& Hodkinson, 2003, p. 5).

\section{Method}

A main purpose of the project was to develop insight into the young people's experiences, assessments and thoughts in the process from the beginning of upper secondary education to adulthood. We have therefore conducted a longitudinal study, following young people since they began first year at upper secondary school in a vocational education program. A total of 32 students 
participated at the start of the project and we interviewed 28 of them five times during a six-year period. The remaining four were interviewed between one and three times since we lost contact with them during the course of the project. In total, the data material consists of 147 interviews.

The research was designed so that we interviewed the students early in the autumn in the first and second years of schooling. The remaining three interviews were made during the years they were apprentices or engaged in other activities. In other words, we followed them through from the age of 16 until they were 22 years old.

As a starting point for the empirical study, three upper secondary schools in three different regions were selected. These schools were located in an urban area, inland and on the coast, and were very different in sizes. In the first interview session, students from seven different vocational education programs participated from these three schools. For the second interview session, all 32 students had continued to their second year, but they were now located in nine different upper secondary schools. However, in the third interview round, the diversity was extensive. Here we found the young people in schools, in training establishments, at work, staying at home due to illness, seeking work, etc. A similar variation was also evident in the fourth and fifth rounds of interviews.

Semi-structured interviews were conducted in all five interviews. Thematic interviews guides were developed before the interviews, and themes and questions came up at the same time in an order that contributed to supporting "a conversational atmosphere" (Bloomer \& Hodkinson, 2000b, p. 69). All interviews were conducted with both researchers in active roles. The young people were asked to describe and reflect on current and past school experiences, telling about events that were important in their lives both just then and in the past, as well as looking forward to possible future plans (where will we find you in 2 years, 5 years, etc.). In the first interview, the young people were asked why they had applied for the particular education program at the actual school, what they thought about the training, what plans they had first for second year, and subsequently afterwards, where they saw themselves in ten years, personal relationships, hobbies, friends, boy-/girlfriend, etc. Through this approach, we attempted to gain insight into their own plans and choices, and to capture contextual relationships that influenced how their learning trajectories were being shaped, developed and/or changed.

All the 147 interviews were recorded and transcribed. Analyses were conducted through a constant comparative method (Glaser \& Strauss, 1967/1999). This involves a procedure whereby the data was studied in detail by reviewing, pausing and asking analytical questions to the data and making continuous comparisons in the search for similarities and differences. The material was coded through "initial" and "focused" coding (Charmaz \& Belgrave, 2012). Through initial coding, fragments of data were studied, while focused coding meant extracting segments in the material that appeared significant in order to view these against larger amounts of data. In this way, the analysis was about moving between the transcribed text, the theoretical thinking about learning 
trajectories and the study's research question. The analyses allowed us to study the learning trajectories horizontally and vertically. Horizontal description includes descriptions of all the students' learning trajectories through one year while vertical description is about descriptions of the same student over several years.

Through the analyses we developed these three major categories: "stayers", "movers" and "leavers". The category "stayers" describes those who completed their planned education in the standard time. The category "movers" describes those who changed course along the way and either completed within five years or completed/are completing after that time. The category "leavers" describes those who did not complete upper secondary education in the period we studied, nor were they in any training course afterwards. They had quit upper secondary education.

\section{Results}

Through the analysis of our data, we have found that the three categories "stayers", "movers" and "leavers" present a complex picture of the pathways, diversions and straying of the young people, through their upper secondary education. They provide a broad description of the different learning trajectories. In our material with the 28 young people that we followed throughout the six-year period, we find thirteen "stayers", seven "movers" and eight "leavers". In the presentation of findings from the survey, selected students are presented within each category. This selection complements a complex picture of different earning trajectories.

\section{«Stayers»}

Six of the thirteen stayers had very clear plans for their course of education when they started at upper secondary school, and they also did this without any deviations. The others had a more or less clear direction for their education. However, common to all thirteen is that through the five interviews we conducted with each of them we can discern coherent narratives about how they achieved their full-time vocational or higher education entrance qualifications within the standard five-year period. Among the stayers we find some young people who had clear education plans and followed them meticulously, and we find others who started high school without clear plans but who adjusted and completed their plans during the five years.

One of those who had clear plans at the start was Konrad. Everything in first interview that was carried out about a month after starting his first year in TIP (Technical and Industrial Production), he outlined plans towards his goal of becoming an agricultural mechanic. He came from a farm and was close to his family and the farm:

"I'm going to complete agricultural machinery mechanics in the second year, but unfortunately that is only offered in the neighbouring town. And then I'll find an apprenticeship in the area up to 10-20 km from home. When I' $m$ finished 
with that, I'll get the trade certificate. I will work for a while and then I am thinking of taking over our farm."

Along the way through his course of training, he kept to these plans. In the second year, he went to a school about $50 \mathrm{~km}$ from his farm but travelled back and forth by bus to avoid moving away from home: "It certainly does mean quite long days". As he had wanted, he then gained an apprenticeship in a company that sold and repaired agricultural machinery. He expressed great satisfaction that he could still live at home, share in the life of the farm and have an apprenticeship where he could "repair tractors, combine harvesters and round balers". Konrad followed his training course as planned without any deviations and received his certificate (of completed apprenticeship) within the standard time.

Another stayer is Susan who we met the first year in Health and Social Studies. She enjoyed this, but was unsure of the way forward:

"I like the vocational subjects but am not so fond of the general subjects. I' $m$ not clever at school, but I think it's exciting to be on practice and to get to try things done in a practical way. [...] I really would like something different, maybe I will take "child care and youth" but I'm not sure if I really want to work with that either because I have been very fond of, or really have a desire to work with the elderly after being on practice in a nursing home. But maybe I'll try for school because I want to be a community worker maybe, or perhaps a child welfare officer ... I really want a lot!"

Susan continued that she has ADD (Attention Deficit Disorder), which means a lack of attention and concentration, and for that reason has received additional help in English and mathematics from fifth class. The difficulties were particularly pronounced in English, but also in other subjects where she needed to keep track of large amounts of content. Susan described her frustrations at upper secondary school concerning what she perceived as lack of support and assistance from teachers and the school to cope with the academic challenges. Susan finally was helped and supported by what she received within close relationships: "This summer, my sweetheart made me watch English movies without the subtitles, so I just had to try. Initially, I had to ask a bit, but after a while I got more and more confident and could watch movies without text. Of course, there is still a lot I don't understand yet, but I've become a lot better!" Furthermore, her sister, who was a teacher student, contributed with her knowledge of sorting information and subjects through using mind maps. "When I read in the usual way, I think of a thousand things and therefore I need to have a mind map, not write everything down on a page, but cut out pieces and hang them on the wall and then place them in a pattern." Despite her challenges, Susan had great determination, and she emphasized the significance of education and anchoring in the near future: "What matters to me is home and family and friends and my sweetheart, and so of course it is important with school and getting an education. It is also important to do well and to keep up with things that are fun. Money is also important in order to cope. " 
Susan proceeded to Health Care Worker the second year, and after many considerations whether she should try to take an additional year to become a nurse, she chose an apprenticeship. She very much enjoyed working in a nursing home, and in the course of four years Susan graduated as a health care worker.

In his first year, George took Technology and Industrial Production because he failed to get into music or media studies. He had already at our first meeting so much absence from school that he was in danger of not being allowed to continue in several subjects. His main interest was to play in a band and party with the gang. George lived mostly with his father, and his father faced a few challenges in terms of jobs and finances. George was not very engaged at school: "I really am just sick of school, all the time. I don't like going to school. But I take a day at a time and then suddenly it's the weekend. [...] I don't think much about the future really, I'm just want to finish this here now and don't think about what happens next year." However, George began the following year in Industrial Mechanic. But he was not very interested and poorly motivated. In addition, he described the class as "the worst gang in the whole school". Relatively early in the autumn, he didn't bother to attend at all. After he had been away for two consecutive weeks, he was contacted by the school and eventually entered in to things up until he changed course to Chemical Processing. When we met George late in the autumn he expressed the following: "It is much more interesting and advanced here. I want to be a process operator!

He made it through his second year, and later told that the school, in cooperation with the training office, made sure that he applied for an apprenticeship in the process operating course at a large company. He achieved this, and at our third meeting with George he came to the interview wearing the company's work outfit sporting a well-known logo. He had only a limited time to talk, because he could not be late at work. George was clearly proud to be employed by a large, well-known company. He experienced that he had significance and was appreciated, performing an important job. There was no longer any problem with absence and playing in a band was leisure activity that was no longer at the forefront of the conversation about what was important in his life.

These three stayers have all completed upper secondary education in the standard time, but still the learning trajectories of the three vary greatly. Konrad took a direct path through his vocational education according to his original plan. He held a stable course and completed it in the standard time. Susan and George, on the other hand, had learning trajectories that could equally have ended up with dropping out. They approached the edge of staying in an education course.

\section{«Movers»}

In the "movers" category there are seven young people with learning trajectories which means that they are not following streamlined training courses. In this category there are three who were able to complete a vocational or academic higher education qualification within five years, even though they changed their 
course along the way. Four of these young people, on the other hand, did not complete their education within five years. Thus, statistically, they will be registered as not completed. These three, however, were in a course that led, or would have led them, to a trade qualification even though they have made some detours along the way and spent more than five years on their education.

Lars is one of those who did not complete his education within five years. We first met him as a student in Electricity and Electronics. The second year he took Automation. Lars outlined clear plans for two trade qualifications and a future job in the North Sea. We were therefore greatly surprised when we met Lars in his third year at the school wearing a chef's attire. He had become an enthusiastic and eager student at the first year of Restaurant and Food Processing. Lars pointed out that now he was really on the right road:

"Before I had slightly different plans. I had some thoughts about the North Sea. I think there was slightly too much thinking about the money rather than doing what I really wanted. I had really wanted to take Restaurant and Food Processing, but I thought that only girls and oddballs took that. But then I decided I would do what I originally wanted to do!"

Lars lived at home with his parents and he said that he discussed his educational choices with his parents, who listened and encouraged him to follow his interests. Afterwards, Lars determined to take the cook course, became an apprentice in a sought-after restaurant and in the last interview, six months after Lars had qualified to be a chef, he worked in a hotel kitchen and was offered a job as assistant manager at the largest hotel in the neighbouring town. In other words, Lars took an educational detour before he found the profession that he really was enthusiastic about. He is interested in his field, has ambitions within the industry and has excelled so much that he has been offered several jobs. At the same time, Lars explained that the detour through Electricity and Electronics contributed valuable perspectives in the route to the career choice he eventually took:

"I'm glad I went to Electricity and Electronics first, otherwise I would not know how well I like the cookery side. I'd rather waste two years instead of wasting my whole life by doing something I do not enjoy. I was a little childish. I made a choice where I allowed myself to be influenced by other people and I thought about money. It's a bit ... stupid. But I must have been rather uncertain then, since I took such a choice. Not mature enough, really, to make a choice that would determine where my life would go."

Something that has largely characterized Lars's experience through his vocational education is that he became a father at the age of eighteen. An important topic in our conversations was his consideration of the balance between the role of father and family man on the one hand and his ambitions in the cookery industry on the other.

We met Sophie first in the autumn in TIP (Technical and Industrial Production) where she was the only girl in the school in this education program. Sophie came from a family with many mechanics where they often spent free time together "tinkering" with cars, scooters, etc. Sophie was genuinely interested in 
her subject and was looking forward to a car mechanic education, hoping one day to work in the Armed Forces. She thought truck mechanic sounded exciting. In the second year she followed her plans, moved to another city where they could offer Motor Vehicles. When we met her, she was aware that the job choice was really right for her, and she enthusiastically talked about how to change a gearbox. In the third year, however, Sophie did not manage to get an apprenticeship and she took Motor Vehicles again to further improve her grades. She had minimal absence and good grades and was therefore sure that now she would get an apprenticeship. She searched many training establishments in several places for a long time, but she told us that time after time she saw that boys were preferred even though she was the best qualified on paper:

"I was at a motor workshop and inquired. They got my application and I had good grades and everything like that. So, I was interviewed and then they said I should get the place. Because no one else had applied. Then, however, a boy turned up, without any CV or application. Just came straight in for an interview and then got the place instead of me. So it's a bit like that, yes .... That's how it went for six or seven workshops, I think. But I'm not giving up yet!"

The closest she came to becoming a mechanic was getting a temporary placement at a motor workshop under NAV (the Norwegian Labour and Welfare Administration) for a short period. She accepted this, even though it meant she had to move to another place. After three years at school and one and a half years searching in vain for an apprenticeship, Sophie gave up and went away from her major goal of becoming a car mechanic. When we met Sophie the sixth year after she started her secondary education, she had begun a more traditional education "for girls" instead. She was working in a placement and training that will lead her to a certificate of completed apprenticeship as a health worker.

These two examples within the category "movers" show that Lars became a mover completely based on his own choice. Sophie, on the other hand, had clear goals, good grades and little absence, but found that she was prevented and blocked in her course of education because she was a girl in a male-dominated industry. Neither Lars nor Sophie achieved their professional competence in the space of five years and statistically speaking are seen as those who have not completed their education.

\section{«Leavers»}

The category "leavers" includes the eight students in our material that were not in a course of education five years after they began upper secondary education.

Lou joined Restaurant and Food Processing. He comes from a family with an Asian background, where enjoyment of food was strong, and the making good food was obviously held in high esteem. He spoke with great warmth about his mother's secret recipe for spring rolls. He moved to lodgings about $100 \mathrm{~km}$ from home to take his second year of study. Lou was still just as enthusiastic, and he participated eagerly in the school's student enterprise. He thought he had 
learned a lot of exciting stuff; for example, he told us in detail how food was flambéed. However, he fared rather worse with the general subjects; "I'm not a big fan of Norwegian and English, no." When we interviewed him in the third year, the Lou we met was less enthusiastic; "School did not go well. I didn't pass in Norwegian or English". Therefore, he was working as a table clearer at a cafe but claimed that he would return to school; "I must go school for the sake of my future". He told us that he actually had dyslexia and maintained that the school would not give him any help. With parents who spoke a foreign language, it was difficult to get help at home for his Norwegian.

In the fourth year, however, we did not find Lou back in upper secondary education: "I am an insurance adviser. So now I'm enjoying myself!" He had also worked in shoe shop and liked that too. Some of what he liked most with these jobs was to go to work smartly dressed and meet customers. He had no plans to attend school again, saying that if he had to choose again, he would have dropped school altogether:

"I think for me personally, school is a waste of time. Sure, you learn a lot of interesting things, but there's a lot of time just thrown away. For example, if you have a dream and get on with that dream, you will come a lot further than getting top grades in Norwegian. School and education are only for those who have a plan B. I'm going for plan A! I'm going to get rich and then I'll need to make some choices that nobody else has. My main goal is to "retire" when I'm forty."

Lou had completely turned around with regard to school attendance. Here, and also in the subsequent data collections, we met a Lou who each time was in a new "life world" characterized by a spin of plans and completely new work contexts. These included phone sales, plans for an investor business in Asia, retail jobs, job at sawmills and ambitions to become a boss for some kind of enterprise, etc. Every time, he had several jobs to earn enough to invest and become wealthy, and also to cover his losses on misplaced investments. $\mathrm{He}$ insisted that school is not important but working hard is important; "You can get to the top by showing a good work ethic and determination. Then you can get ahead."

Another "leaver" is Vera, whom we first met in Restaurant and Food Processing. She appeared to be enjoying school and claimed that she had wanted to take this subject right from when she was very young. Vera struggled with all school subjects and received special additional help. Her school achievement at lower secondary school was poor and she had a challenging family situation with little support.

The next time we met Vera, she had switched to Health, Childhood and Youth Development, but thought it was also difficult. She eventually moved to lodgings near the school where she could have her cats (to whom she was very attached and had great concern for). Vera continued on to Health Care Worker, and she completed her school year but did not pass. In the fourth year, Vera went to a Folk University College (a post-secondary boarding school without formal courses) and expressed the opinion that it was a good school year. In the 
final interviews, we met Vera at different lodgings and in various placements under NAV. In one placement, she quit after one month: "There was so many problems outside of work. I had problems with my cats. The landlord said it smelled of cat pee, so I moved to another town with my cats and I quit my job." Such interruptions and relocations from place to place common in Vera's experience. For a period, she had the desire and motivation for a placement in a second-hand shop. However, when we talked to her a few months after she had begun, Vera's comment was: "I think I'll quit there, because it's so boring doing the same all the time." Vera often used the word boring. She regularly chose short-term solutions, nor did she understand the importance of education or work with a view to earning money and supporting herself.

A third "leaver" is Didrik who started at TIP. He had no academic issues and thought his school subjects were easy. He appeared as a happy lad coping well with most aspects of life, engaged in many things that had nothing to do with school. According to Didrik, his mother had a central role in getting him off to school. In spite of his mother's efforts, he had a lot of absence and did not do his homework; this reflected in his results: "I think teachers see me as a student who can do a super job when I first started at school. I'm good at being careful with my work I'm doing, but the teachers think it's stupid that I have so much absence when I am so clever." Didrik did not see any need for an education: "I take one day at a time and I see what I am doing. Mum wants me to finish school, but there's not much for her to say because she has no education herself." Education was not part of his plan for his life. His father ran a successful company and Didrik pointed out that he could get a job there with good salary any day. Didrik took a second year at school but failed some of his subjects because "they were so boring". At subsequent data collections, it also turned out that Didrik had finished school and was working in his father's business. He thought life was good and did not express at any time the need for an education or any concern for the future.

The examples above show that each of these three did not complete upper secondary education for very different reasons. Lou was highly motivated for education in the restaurant and food-processing field but failed in the general subjects. Vera came from a difficult family background and had challenges with all her subjects. Neither of these two met the requirements for school, while Didrik on the other hand, always had an opening into his father's company and therefore chose to drop further training.

\section{Discussion}

The analyses of the young people's descriptions, understandings and experiences of choices and assessments are presented through the analytical categories "stayers", "movers" and "leavers". In the presentation of the findings above, eight of the young people's learning trajectories are described in more detail. In Norway, dropping out is defined as when a student has not completed upper secondary education with vocational or higher education entrance qualification within five years after starting. Five of the young people described 
in the analyses are thus included in the official statistics of youth who have not completed upper secondary education within five years. This applies to the two from the category "movers" and the three from the "leavers" category. The eight descriptions, however, show that the dichotomy of dropout and completion does not capture the complexity of the learning trajectories of these young people through an educational course.

\section{Unpredictable and complex learning trajectories}

The most important factors for explaining the outcome of upper secondary education are the students' backgrounds, involvement with the school and previous school achievements (Markussen, 2016, p. 32). The stayer, Konrad, completed his education at the appointed time without encountering notable challenges. Features for Konrad were that he had good results from the lower secondary school, received good support from home and identified himself with and engaged in school. However, the learning trajectories of the two other stayers, Susan and George, were more complicated. Susan had a great deal of commitment to the school and to the vocation she had chosen. She also had support from her family but struggled in her subjects for lower and upper secondary school. An important factor for her mastery of the general subjects was the help she received from her close friends. George did not have any academic problems. However, he did not engage with the school nor had he any support from home that could help him with the challenges he experienced along the way, such as getting to school. The decisive factor for George was the close monitoring from the school. Susan and George were both in a situation where they had major challenges that had significance for their learning trajectories. These learning trajectories could just as easily have ended up with dropout as with completion.

The two "movers", Lars and Sophie, had no academic challenges. They came from homes that supported them in their course of education and they had a great deal of involvement with the school and the subjects. Lars's learning trajectory was characterized by the fact that he initially did not choose the education program he was most interested in, but one that he thought would lead to a well-paid job. After two years, in consultation with his parents, he made a decision to go to his original primary desire with regard to education. Sophie's learning trajectory was characterized by her major involvement with automotive mechanics. She even took the second year of study again to ensure even better grades and thus entrance to an apprenticeship. But Sophie realized that the road to automotive mechanic was arduous and inaccessible. The alternative Sophie finally chose was to start training for a traditional female role. Both Lars and Sophie appear in the statistics as if they dropped out of upper secondary education. In fact, both of them have completed their vocational education. Lars took one year longer than the standard five years. In Sophie's case, her course of education will take a considerably longer time since she spent four and a half years trying to be accepted to complete her training as a car mechanic. 
Three "leavers" were described in the analysis. Lou had bad grades from lower secondary school. He came from a family where the importance of education was not highlighted. He was eager to take the restaurant and food processing course but left upper secondary education after having failed in English and Norwegian in his second year. Vera had a very challenging family background with little stability or sense of belonging. She had major academic challenges in elementary school and the subjects in upper secondary education were also very difficult. She did not identify with school and showed little commitment to either the school or the workplaces she was sent to. Didrik, on the other hand, had no academic problems and had parents who supported him, but he did not see any point with schooling. His involvement was not related to education.

\section{The significance of support}

A common thread in the interviews with these young people is their need for help and support in various forms and in different contexts throughout the course of their education. Some received this support, others experienced that the help they needed did not appear to be available for them. The most striking example of the importance of support in the course of education is perhaps Lou, who lacked support from home and found that school did not deal with his dyslexia and his need for help in the language subjects in his second year. This meant that, despite his extensive academic involvement, he failed in Norwegian and English. Thus, he dropped out of upper secondary education, and Lou could not see how he could get into a learning trajectory that would lead him into the profession he wanted. As a consequence of this, as time went by, he tried more and more to convince himself and the world that education is not important. Lou had a need for academic support. Vera, in addition to academic challenges, also had a clear need for some kind of personal support to succeed in an educational course or in employment over time and to understand that one does not quit, move to a new house or give up due to acute problems with cats or if the job is somewhat monotonous. The stayers, Susan and George could just as easily have fallen out of their courses, but crucial for them was that they received the support they needed to continue their education. Susan gained this from her close relationships, while George was recognised as needing help and received the necessary guidance and support from her school.

What affects success in upper secondary education most is young people's backgrounds, past achievements and engagement with the school (Markussen, 2016). All of these are individual conditions related to the individual student's prerequisites and situation. In our qualitative, longitudinal study, we see clearly that these are essential factors. However, an individual-oriented explanation is insufficient to understand the complexity of the young people's learning trajectories. This is because, in addition to individual circumstances, we see that external conditions of a processual and system-oriented nature may also occur. For example, it was crucial for George's success in school that the school actively helped him to plan a new pathway and helped in the process of getting an apprenticeship. In Sophie's case, there were no individual circumstances that meant that she did not complete secondary education within five years. For her 
it was decisive that she did not get an apprenticeship even though she had good grades, great dedication and few absences.

There are individual factors that are of great importance for the students' risks for dropping out of school. However, as shown above, different types of support are vitally important to the learning trajectories of young people. For example, it is very important that the school finds, and offers help for, academic problems early on. Also, in terms of absence and behaviour, the school's involvement is crucial. A major study of upper secondary education in Denmark points out that the learning environment, the teaching methods and the teachers' involvement are important for keeping students, especially those students who are in some way vulnerable (Katznelson \& Pless, 2007). Here too, the important of taking into account the individual student's prerequisites it is emphasized, and the provision of close follow-up through academic and personal support, as well as cooperation with external bodies, in order to meet complex challenges through a comprehensive approach.

\section{Upper secondary education for all?}

Our study of the thoughts, perceptions and experiences of the 32 young people in relation to their education - and to life as a whole - lasted six years. The results show that each individual's learning trajectory was unique and that very few of these trajectories were predictable and/or linear. In this phase of life, decisive choices are made for the future at the same time as uncertainty, vulnerability, identity development, etc., are affecting the lives of the young people.

The dropout rate from vocational education programs in Norway has been high for many years, and statistically speaking, this dropout rate has a major impact on the future course of life for young people in terms of employment, prosperity and health. However, in the debate about dropout and completion, it is important to look beyond the individual factors. Reegård and Rogstad (2016, p. 201) point out that in the public debate and formulation of initiatives there is an increasing individualization of the dropout problem with a focus on factors such as low grades, high absenteeism, reading and writing difficulties, psychological challenges, etc. On the one hand, this can lead to measures being aimed at early involvement and assistance. On the other hand, such a focus on negative factors in the individual can lead to "dropout rates being considered as a result of 'problems' in the young" (ibid.). It is a fact that socioeconomic backgrounds are most crucial for young people's school results. This is a factor outside the scope of the education system, but in addition to background and conditions in upbringing, both the design of education in the individual school and classroom, as well as the design and organisation of the school system itself, are of great importance.

After completing this six-year study where we have followed these 32 young people relatively closely through their years of youth, we are left with a lot to wonder about and reflect on. We have seen how some of the young people struggle to fit into a school system that in many ways does not suit them. One 
can raise questions as to whether a more differentiated and varied approach can be developed to gain a vocational certificate or higher education entrance qualification. Perhaps one could imagine the education system being more adapted to the diversity of pupils rather than that the students must at all costs adapt to the education system in order to complete their upper secondary education.

In the public discussion about young people who do not complete their education, the words "quitter" and "dropout" are usually used. These terms have a negative ring to them and may be experienced as stigmatizing. They tend to associate students who do not meet the school's academic requirements as not being able to cope with school and who end up with NAV. In our study we do not find this pattern. The young people are actors in their own lives, and several of those who are in the statistics as dropouts have made thoughtful re-selection for their life. The official definition of dropout is different from country to country. In Norway, dropping out is defined as when a student has not completed upper secondary education with vocational or higher education entrance qualification within five years from when they start. This may be a contributing factor to the high dropout rate. For example, dropouts in Denmark are defined as those who did not pass upper secondary education within 25 years of completing primary school, while in Iceland, it is reckoned as those who have failed to complete upper secondary education or is still in education at the age of 24 (Markussen, 2011). Norway in other words, has a very narrow definition, and one of the things we have discovered is that several of the young people in our study would have avoided the dropout label if this five-year limit had been extended.

\section{References}

Barry, M. \& Reschly, AL (2012). Longitudinal Predictors of High School Completion. School Psychology Quarterly 27(2), 74-84.

Beekhoven, S., \& Dekkers, H. (2005). Early school leaving in the lower vocational track: Triangulation of qualitative and quantitative data. Adolescence, 40(157), 197-213.

Bloomer, M. \& Hodkinson, P. (2000a). Learning careers: Continuity and change in young people's dispositions to learning. British Journal of Educational Studies, 26(5), 583598.

Bloomer, M. \& Hodkinson, P. (2000b). The complexity and unpredictability of young people's learning careers. Education and Training, 42(2), 68-74.

Byrhagen, K. N., Falch, T. \& Strøm, B. (2006). Frafall i videregående opplæring: Betydningen av grunnskolekarakterer, studieretning og fylke.[Dropout in upper secondary education: The importance of elementary school grades, field of study and county] SØF-rapport nr. 08/06. Trondheim: NTNU, Senter for økonomisk forskning.

Charmaz, K., Belgrave, L. (2012). Qualitative interviewing and grounded theory analysis. I J. Gubrium, J. A. Holstein, A. Marvasti, \& K. M. Marvasti, K. M. (red.), Handbook of interview research (2. utg.) (s. 347-365). Thousand Oaks, CA: Sage. 
Falch, T., Johannesen, A. B. \& Strøm, B. (2009). Kostnader av frafall i videregående opplæring. [Cost of dropout in upper secondary education]. SØF-rapport nr. 08/09. Trondheim: NTNU, Senter for økonomisk forskning.

Falch, T. \& Nyhus, O.H. (2009). Frafall fra videregående opplering og arbeidsmarkedstilknytning for unge voksne. [Dropout from upper secondary education and employment for young adults].SØF-rapport nr. 07/09. Trondheim: NTNU, Senter for økonomisk forskning.

Fry, R. (2003). Hispanic youth dropping out of US schools: Measuring the challenge. Washington D.C.: Pew Hispanic Centre.

Glaser, B. G. \& Strauss, A. L. (1967/1999). The discovery of grounded theory. Strategies for qualitative research. New York: Aldine de Gruyter.

Hodkinson, P. \& Hodkinson, H. (2003). Individuals, communities of practice and the policy context: school teachers' learning in their workplace. Studies in Continuing Education, 25(1), 3-21.

Katznelson, N \& Pless, M. (2007). Unges veje mod ungdomsuddannelserne. København: Center for Ungdomsforskning.

Kuczera, M., Brunello, G., Field, S. \& Hoffman, N. (2008). Learning for jobs: OECD reviews of vocational education and training Norway. Retrieved October 12, 2017, from http://www.oecd.org/dataoecd/45/34/41506628.pdf

Lahn, L. (2011). Professional learning as epistemic trajectories. I S. Ludvigsen, A. Lund, R. Rasmussen, \& R. Säljö (red.), Learning across sites. New tools, infrastructures and practices (s. 53-68). Abingdon: Routledge.

Lamb, S., Markussen, E., Teese, R., Sandberg, N., \& Polesel, J. (red.) (2011). School dropout and completion: international comparative studies in theory and policy. Springer: Dordrecht.

Land, D., \& Legters, N. (2002). The extent and consequences of risk in US education. In S. Stringfield, \& D. Land (Eds.), Educating at-risk students: One hundred-first yearbook of the national society for the study of education (s. 1-28). Chicago: University of Chicago Press.

Lillejord, S., Halvorsrud, K., Ruud, E., Morgan, K., Freyr, T., Fischer-Griffiths, P., Eikeland, O. J., Hauge, T. E., Homme, A. D. \& Manger, T. (2015). Frafall $i$ videregående opplæring. En systematisk kunnskapsoversikt. [Dropout in upper secondary education. A systematic knowledge overview]. Oslo: Kunnskapssenter for utdanning.

Markussen, E. (2016). Forskjell på folk! I K. Reegård \& J. Rogstad (red.), De frafalne. Om frafall $i$ videregående opplæring - hvem er de, hva vil de og hva kan gjøres? [The dropouts. About dropout in upper secondary education - who are they, what do they want and what can be done?]. (s. 22-61). Oslo: Gyldendal Akademisk.

Markussen, E. (2011). Frafall i videregående opplæring - i Norge og andre land. [Dropout in upper secondary education - in Norway and other countries]. Bedre Skole 1, s. 10-15.

Markussen, E., Frøseth, M.W. \& Sandberg, N. (2011). Reaching for the unreachable: Identifying factors predicting early school leaving and non-completion in Norwegian upper secondary education. Scandinavian Journal of Educational Research 55(3), s. 225-253.

Patterson, J. A., Hale, D. \& Stessman, M. (2007). Cultural contradictions and school leaving: A case study of an urban high school. The High School Journal, 91(2), 1-15. 
Reegård, K. \& Rogstad, J. (2016). Avsluttende randbemerkninger. [Final edge notes]. I K. Reegård \& J. Rogstad (red.), De frafalne. Om frafall i videregående opplæring - hvem er de, hva vil de og hva kan gjøres? (s. 199-207). Oslo: Gyldendal.

Rumberger, R.W. (2011). Dropping out. Why students drop out of high school and what can be done about it. Cambridge Mass.: Harvard University Press.

Statistisk sentralbyrå (2017). Gjennomføring $i$ videregående oppæring. [Implementation in upper secondary education]. Retrieved January 3, 2018 from https://www.ssb.no/vgogjen

Vibe, N., Frøseth, M.W., Hovdhaugen, E. \& Markussen, E. (2012). Strukturer og konjunkturer. Evaluering av Kunnskapsløftet. Sluttrapport fra prosjektet «Tilbudsstruktur, gjennomføring og kompetanseoppnåelse i videregående opplæring» [Structures and developmental cycles. Evaluation of the reform Knowledge Promotion. Final report from the project «Offer structure, implementation and competence achievement in upper secondary education»]. Rapport 26/12. Oslo: NIFU.

Wittek, L. (2013). Sjanger som struktur for doktorgradsløpet og veien videre som forsker. [Genre as a structure for the PhD course and the way forward as a researcher]. Uniped 36(4), 5-19. DOI: 10.3402/uniped.v36i4.23146

Wittek, L. \& Bratholm, B. (2014). Læringsbaner - om lærernes læring og praksis. [Learning trajectories - about teachers' learning and practice]. Oslo: Cappelen Damm Akademisk. 